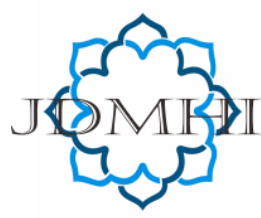

email: jdmhi@walisongo.ac.id

Journal of Digital Marketing and Halal Industry

ISSN: 2716-4810 (print) ISSN: 2716-4802 (online)

\title{
Analysis of Factors that Increase Customer Satisfaction Coffee Products
}

\section{Doni Nurdeagraha, Edy Suryawardana}

\author{
Universitas Semarang, Indonesia
}

\section{A R T I C LE I N F O}

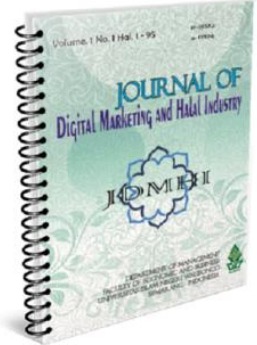

Article history:

Received 7 September 2020

Accepted 22 October 2020

Published 30 October 2020

Keywords:

Customer Satisfaction, Price,

Service Quality, Product Quality,

Product Diversity, Promotion, and Location
A B S T R A C T

Satisfaction is the level of feeling where someone states the comparison of the product's performance (service) received and expected. This study aimed to determine the effect of price, service quality, product quality, product diversity, promotion, and location on customer satisfaction. This study uses a quantitative approach. The sample is the consumer "P" Coffe Gajahmada Semarang branch. The sampling technique used purposive sampling-sources of data were obtained through the distribution of closed-question questionnaires. The data analysis technique used multiple linear regression analysis. Hypothesis test results show that price, service quality, product quality, product diversity, promotion, and location have a positive and significant effect because all independent variables have a significant probability value $<0.05$. The coefficient of determination showed 0.845 or $84.5 \%$. It is necessary to increase product diversity in the form of completeness, brand, and variety in the future.

\section{@2020 Journal of Digital Marketing and Halal Industry}

\section{Introduction}

Along with the advancement of civilization, human life and culture and the development of globalization have led to a shift in cultural values from a social society to a more individual tendency. Busyness and high mobility make urban people need a place to relieve fatigue after carrying out their daily routines. Activities carried out to alleviate fatigue are usually by relaxing, eating, drinking, listening to music, or just gathering and chatting with relatives or friends in the community. Seizing this opportunity and shifting people's lifestyles that make these activities part of life necessities make business people more interested in managing their business. This business actor's presence is

* Corresponding author.email: edysuryadarwan@usm.ac.id DOI: http://dx.doi.org/10.21580/jdmhi.2020.2.2.6352 
considered to be the most following the current trend and lifestyle of urbanites.

In facing an increasingly fierce business competition, especially competition from similar companies, companies are increasingly required to move faster in terms of attracting consumers. Companies that apply the concept of marketing need to pay attention to consumer behavior and the factors that influence their purchasing decisions in the marketing efforts of a product. In the image, one way to achieve company goals is to know what the needs and desires of consumers or target markets are and provide the expected satisfaction more effectively and efficiently than competitors (Kotler, 1996).

One of the service products that feel the tight competition in service companies today is the Coffee Shop business. A coffee shop in Semarang has become a daily sight, especially among college students and students. Various names and types of food and drinks are offered from traditional to modern, which is what is happening in the new era of the coffee shop generation. It is undeniable that student and student life in Semarang cannot be separated from the nightlife from hanging out in cafes, hanging out, clubbing, and others, which all form into one community and become the embodiment of a modernization culture.

A local company engaged in selling coffee drinks in Semarang is "P" Coffee, a coffee shop located in Jalan Gajah Mada, Semarang, and was founded in 2013. "P" Coffee is a coffee shop that is open 24 hours a day. "P" Coffee provides coffee drinks for visitors at competitive prices and is equipped with a variety of other food and beverage menus.
Also, to increase convenience for its customers, "P" Coffee provides a wifi facility for customers who want to access the internet. The hope of "P" Coffee by providing complete facilities and facilities and attracting customers is an increase in the popularity of "P" Coffee, which in turn will have an impact on increasing sales of "P" Coffee. However, in reality, the opposite can be seen in the decrease in coffee per-piece sales each year. There was a significant decrease from 2014 to 2015 , amounting to 2,817 per piece. This data indicates that the "P" coffee is experiencing severe problems, so that it needs to be fixed as quickly and as possible. In this case, the service strategy and price provisions applied by the "P" coffee do not meet consumer desires, making consumers feel dissatisfied. The data above is also supported by data on consumer complaints "P" coffee Gajah Mada Semarang. The following is the data on consumer complaints "P" coffee Gajah Mada Semarang 2016:

Table 1. Table of Consumer Complaints "P" Coffe Gajah Mada Semarang

\begin{tabular}{|c|c|c|c|}
\hline No & Aspect & complaints & $\%$ \\
\hline & The price is too high & 60 & $24 \%$ \\
\hline & Coffee quality is lacking & 35 & $14 \%$ \\
\hline & The less large parking area & 27 & $11 \%$ \\
\hline & $\begin{array}{l}\text { Lack of payment facilities using a } \\
\text { debit }\end{array}$ & 10 & $4 \%$ \\
\hline & $\begin{array}{l}\text { Lack of coffee variants } \\
\text { The comfort for consumers is not }\end{array}$ & 34 & $14 \%$ \\
\hline & $\begin{array}{l}\text { paid attention to because the place } \\
\text { is narrow }\end{array}$ & 12 & $5 \%$ \\
\hline & $\begin{array}{l}\text { Barista service is not satisfactory to } \\
\text { consumers }\end{array}$ & 40 & $16 \%$ \\
\hline 8 & $\begin{array}{l}\text { The cleanliness is lacking because } \\
\text { there are lots of mosquitoes }\end{array}$ & 15 & $6 \%$ \\
\hline & $\begin{array}{l}\text { There are still many people who } \\
\text { don't know about "P" coffee }\end{array}$ & 17 & $7 \%$ \\
\hline
\end{tabular}

Source: Consumer "P" Coffe Gajah Mada Semarang 
Based on Table 1 above, the total number of complaints above is a total of 250 complaints. The protests above are dominated by various things, namely (1) high price, (2) unsatisfactory barista service, (3) lack of coffee quality, (4) lack of coffee variants, and so on.

According to Kotler and Keller (2010), price is the amount of money exchanged for a product or service. Furthermore, price is the sum of all the value consumers exchange for the number of benefits by owning or using a good and service. Price is a determining factor influencing purchase choices, and this is still a reality in third world countries, among low social groups, and daily staples. According to Assegaf (2009), service quality is an economic activity that produces or produces time, place, form, and psychological needs or needs. From the above opinion, it can be concluded that service quality is a level of ability (ability) of the company in providing everything that the customers expect in fulfilling their needs.

According to Kotler and Keller (2010), product quality is one factor determining the level of consumer satisfaction after purchasing and using a product. The resulting product planning must be following the needs of consumers. Also, the resulting product must reflect good quality. According to Kotler and Keller (2009), product diversity is a collection of all products and goods offered for sale by a particular seller. The variety of products produced by a company includes the width, length, depth, and consistency of the product mix (Kotler and Keller, 2009). Width, i.e., it refers to how many different product lines the company sells. The length refers to the total number of products in the mix. Depth refers to the number of variants offered by each product in that line, and the consistency of the product mix refers to how closely the various product lines are related to the end-user. This product diversity can work if the company is innovative in creating new products or variations on its products. Companies do all these things to increase consumer purchases because consumers tend to choose diverse and complete products. According to Buchari Alma (2006) are: Promotion is a type of communication that provides explanations and convinces potential consumers about goods and services to get attention, educating, reminding, and convincing potential consumers.

Based on the background mentioned above, the problems faced by "P" Coffe show that the level of consumer satisfaction has decreased, as evidenced by the many complaints about price, quality of service, quality of coffee, lack of coffee variants, promotions, and locations. The impact of these consumers' dissatisfaction affects decreasing the number of coffee sales per-piece. This study aims to identify the effect of price, service quality, product quality, product diversity, promotion, and location on customer satisfaction.

\section{Literature Review}

\section{Price}

According to Swastha (2009), price is the amount of money (plus some items if possible) needed to get a combination of goods and their servants. Usually, marketers set prices for a variety of:

1. Specific goods/services that are the object of the transaction

2. Several complimentary services

3. Benefits of satisfying the needs given the product in question. 
So from the above opinion it can be concluded that price is an essential part of the marketing mix used to obtain goods or services and use it for a certain amount of money. Pricing is always a problem for every company because fixing this price is not the absolute power or authority of an entrepreneur. With pricing, the company can create sales revenue from the products it produces and markets. The role of price fixing will be significant, especially in increasingly intense competition and limited demand developments. The price is substantial, especially to maintain and improve its position in the market and increase sales and company profits.

The objectives of pricing, according to (Rahman, 2010) include the following:

1. Income-oriented goals

Most businesses are revenue-oriented, with only non-profit or public service companies focused on the break-even point.

2. Capacity-oriented goals

Several business sectors usually synchronize supply and demand and utilize maximum production capacity.

3. Customer-oriented goals

Usually, the pricing given is quite representative by accommodating all types of customers, market segments, and purchasing power differences. You can use a system of discounts, bonuses, and others.

\section{Service quality}

Quality is a company's weapon to win the competition, but almost all companies, especially companies engaged in services, strive to produce the same rate. For this reason, quality is not the only effective way a company takes to be able to compete with its components. According to the American Society For Quality Control, quality is the overall characteristics and characteristics of a product or service in terms of its ability to meet current needs determined or latent (Lupiyoadi, 2016).

According to Parasuraman et al. in ( $R$, Puspitasari, Susanty, Andini, \& Rumita, 2020) service quality is a concept that is difficult to see and blur, so there are often errors in determining the nature of quality as goodness or luxury or business or weight. Service quality is a concept that accurately represents the essence of the performance of a service, namely the comparison to reliability (excellence) in-service encounters made by consumers. Service quality is described as a form of attitude resulting from a comparison of customer service quality expectations with its perceived customer performance.

Parasuraman et al. in (R, Puspitasari, Susanty, Andini, \& Rumita, 2020), revealed three service characteristics that must be observed to understand the concept of service quality, namely:

1. Service is intangible (intangibility) because the form of service is the performance of an object, so the density and uniformity of manufacturing specifications are often not realized in one unit. Generally, services cannot be counted, measured, stored, felt, and proven to increase sales as a guarantee of quality. Given the nature of its non-existence, service 
companies often find it difficult to know how consumers perceive their services and evaluate their quality.

2. Especially labor-intensive services are heterogeneous (heterogeneity): their performance often varies from producer to producer. Consistency in service personnel's behavior is difficult to guarantee because what companies deliver to consumers may be entirely different from what consumers receive.

3. The process that occurs between the production and consumption of services cannot be separated. Consequently, the service's quality is not made at the manufacturer's location and then sent in full to the consumer.

\section{Product quality}

Products are tangible or intangible objects that people can buy (Harjanto, 2009). According to Kotler and Armstrong (2008), the definition of product quality is a set of characteristic features of goods and services that have the ability to meet needs, which is an understanding of a combination of durability, reliability, accuracy, ease of maintenance, and other attributes of a product.

Products are everything that can be offered to the market to satisfy wants or needs (Kotler \& Keller, 2009). Juran in (Kristiana 2014) product quality is the suitability of product use (fitness for help) to meet consumer needs and satisfaction. Nasution in (Sufiyanti, Sayutu, \& Windarti, 2017) product quality is a dynamic condition related to products, people/labor, processes and tasks, and the environment that meets or exceeds consumer expectations. (Tjiptono, 2014) defines quality as the level of quality expected and control of diversity in achieving that quality fulfilling consumer needs; meanwhile, according to Kotler and Amstrong (2008), product quality is the ability of a product to carry out its functions, including durability, reliability, ease of operation and repair, and value attributes. From the definition above, it can be concluded that product quality is a condition in which consumers feel that they are compatible with a product or following the wishes expected to meet their needs.

\section{Promotion}

A company in marketing its products needs to design and disseminate information about its presence, availability, product characteristics, and production conditions, and the benefits that customers / prospective customers can get for the products offered by the company. Promotional strategies carry out efforts to introduce products to the market. The concept used to introduce the product is a promotion mix that combines product advantages and persuades consumers to buy (Swastha, 2014).

The effort that needs to be done is through promotion as a series of overall marketing plans. This strategy is a communication process aimed at influencing consumer behavior towards making positive purchasing decisions for the company. Promotion, according to Mc. Charity \& Perreault (quoted by Suwarni, 2009) "Promotion is information communication between sellers and prospective buyers or other parties in the channel to influence attitudes and behavior."

\section{Location}

Determining a location for each business is an essential task for marketers because the wrong 
decision can lead to failure before the company starts. Choosing a trading location is an important decision for a business that must persuade customers to come to the business to fulfill their needs.

The choice of location has a strategic function because it can help determine the achievement of the business entity's objectives. Location more explicitly means a physical place (Sriyadi, 1991). Site is the location or retail store in a strategic area to maximize profits (Basu Swasta and Irawan, 2003).

Meanwhile, according to (Lupiyoadi 2016) explained, the location is where the company must be headquartered to carry out operations. In this case, there are three types of interactions that affect the location, namely:

1. Consumers come to the service provider (company). If the situation is like this, then the location is significant. Companies should choose a place close to consumers so that it is easily accessible. In other words, it must be strategic;

2. Service providers visit consumers. In this case, location is not very important but what must be considered is that service delivery must remain of high quality;

3. Service providers and consumers do not meet in person, which means that service providers and consumers interact through specific means such as telephone, computer, and mail.

Based on this theory, a strategic location from consumers' reach, including transportation access, sales locations, and the distance from the shop to the house.

\section{Customer Satisfaction}

Satisfaction is the level of feeling where a person states the comparison of the product's performance (service) received and expected (Kotler, 1997). The company gets many benefits by achieving a high level of customer satisfaction. High levels of customer satisfaction can increase customer loyalty, prevent customer turnover, reduce customer sensitivity to prices, reduce marketing failure costs, reduce operating costs caused by increasing the number of customers, increase advertising effectiveness, and improve business reputation (Fornell, 1992). Customer satisfaction's primary determinant is the customer perception of service quality (Zeithamal and Bitner, 1996).

According to Schnaars (Tjiptono 2014), the purpose of a business is to create satisfied consumers. Every person or organization (company) must work with internal and external consumers to meet their needs in collaboration with internal and external suppliers to create customer satisfaction. The creation of consumer aging can provide several benefits, including (Tjiptono 2003):

1. The company's relationship with consumers is harmonious

2. Provides a reasonable basis for repeat purchases

3. Can encourage consumer loyalty

4. Forms word of mouth recommendations that benefit the company

5. The profit earned increases.

\section{The Method, data, and analysis}

The population is a generalization area 
consisting of objects/subjects with specific qualities and characteristics determined by the researcher to be studied. Sugiyono (2009) In this study, the population is an unknown number of consumers who visit the "P" Coffe.

Sampling was carried out using nonprobability sampling techniques, namely, by using purposive sampling. According to Sugiyono (2009), the nonprobability selection is a sampling technique that does not provide equal opportunities or opportunities for each element or member of the population to be selected as samples. This criterion is that every consumer who buys coffee at "P" coffee on his own will and is in the city of Semarang who has made a purchase can quickly become a sample member by distributing a questionnaire to each consumer. Based on the results of calculations using the Slovin formula, the number of samples used was 96.04. It is then rounded off to 96 respondents. So, the number of pieces that will be used in this study is 96 respondents. The research will be analyzed using multiple linear regression analysis methods. The data obtained from the field were then processed using SPSS 24.00.

\section{Result and Discussion}

The Effect of Price on Customer Satisfaction "P" Coffee Semarang

The price regression coefficient is 0.178 . The price regression coefficient is positive, and it shows that every price increase is 1 (one), and the variable service quality, product quality, product diversity, promotion, location is 0 (fixed). The consumer satisfaction variable "P" Coffee has increased by 0.178 .

Based on the statistical calculation results with a partial test, the price positively and significantly affects consumer satisfaction "P" Coffee Semarang because it produces a significance value of $0.039<\alpha=0.05$. The hypothesis that has been formulated according to the results of the study, namely price, has a positive and significant effect on customer satisfaction "P" Coffee Semarang.

The price of food and beverages offered by "P" Coffee Semarang follows the quality, taste, and portion given. Meanwhile, the price offered is quite competitive with other food stalls, which shows that the price is not much different from other food stalls. Apart from that, the cost of food and beverages offered is affordable for consumers' purchasing power. This shows that customer satisfaction is significant so that there is still enough money to spend from the income they have to eat and drink at "P" Coffee Semarang. The research is in line with the study conducted by Saradissa (2015), which states that price has a positive effect on consumer butterflies Ijen Café $\mathrm{N}$ Resto Surabaya. Likewise, with the research of Runtunguwu et al. (2014), the price has a positive impact on user satisfaction of café and restaurant cabana Manado.

\section{Effect of Service Quality on Customer Satisfaction "P" Coffee Semarang}

Service quality regression coefficient of 0.211. The service quality regression coefficient is positive, and it shows that each quality increase is 1 (one), and the price variable, product quality, product diversity, promotion, location is 0 (fixed). The consumer satisfaction variable "P" Coffee has increased by 0.211 . The results of statistical calculations with partial tests show that service quality has a positive and significant effect on customer satisfaction "P" Coffee Semarang because it 
produces a significance value of $0.017<\alpha=$ 0.05. The hypothesis formulated following the results of research, namely service quality, has a positive and significant effect on customer satisfaction "P" Coffee Semarang.

This indicates that the higher the service quality of "P" Coffee Semarang to the level of responsiveness of "P" Coffee Semarang employees, the positive reliability of "P" Coffee Semarang employees in the minds of consumers, guarantees for users, comfort in using "P" Coffee Semarang facilities. , the cleanliness of "P" Coffee Semarang, and the level of availability of a good "P" Coffee Semarang facility, the better the level of service quality capability in arousing consumer liking, consumer confidence, and consumer satisfaction for visiting "P" Coffee Semarang.

This study's results are in line with previous research by Nainggolan et al. (2016) that service quality positively affects customer satisfaction at Stove Syndicate Café customers in Semarang. This shows that coffee service providers' reliability can be seen from the accuracy in delivering customer orders. Responsiveness in the presentation and service to consumers' wants and needs can improve service quality, thus affecting customer satisfaction.

\section{The Effect of Product Quality on Customer Satisfaction "P" Coffee Semarang}

The product quality regression coefficient is 0.147. The product quality regression coefficient is positive. It shows that every increase in the product quality variable is 1 (one), and the price variable, service quality, product diversity, promotion, location is 0 (fixed). The consumer satisfaction variable "P" Coffee has increased amounted to 0.147.
Based on the statistical calculation results with partial tests, product quality has a positive and significant effect on customer satisfaction "P" Coffee Semarang because it produces a significance value of $0.041<\alpha=0.05$. The hypothesis formulated following the results of research, namely product quality has a positive and significant effect on customer satisfaction "P" Coffee Semarang.

Product quality is the overall quality or superiority of a product or service expected by the customer. The quality of food and drinks served by "P" Coffee Semarang has the menu's suitability, features, and pleasing aesthetics in terms of shape and taste. This quality makes the assessment of consumer satisfaction high so that consumers want to visit "P" Coffee Semarang. This study's results are in line with previous research conducted by (Habibah \& Sumiati, 2016). The product quality has a positive effect on consumer satisfaction in KOPIKITA Semarang consumers. The analysis of Ransunali et al. (2015) product quality positively affects user satisfaction at the Ocean 27 Manado Restaurant.

\section{Effect of Product Diversity on Customer Satisfaction "P" Coffee Semarang}

The product quality regression coefficient is 0.183. The product quality regression coefficient is positive, it shows that every increase in the product diversity variable is 1 (one) and the price variable, service quality, product quality, promotion, location is 0 (fixed), then the consumer satisfaction variable "P" Coffee has increased. amounting to 0.183. Based on the results of statistical calculations with partial tests, product diversity has a positive and significant effect on customer satisfaction "P" Coffee Semarang because it 
produces a significance value of $0.043<\alpha=$ 0.05. So that the hypothesis that has been formulated in accordance with the results of the study, namely product diversity has a positive and significant effect on customer satisfaction "P" Coffee Semarang. According to Kotler (2007) product diversity is a collection of all products and goods offered by certain sellers to buyers. The consumer assessment of "P" Coffee Semarang on product diversity shows that the completeness of the product, product brand, size variation, and product quality variation on offer is still standard. However, the product design offered by "P" Coffee Semarang is very attractive to consumers, this is quite influential on consumer satisfaction. The results of this study are in line with previous research conducted by Nainggolan (2016), which states that product diversity has a positive and significant effect on customer satisfaction.

\section{The Effect of Promotion on Customer Satisfaction "P" Coffee Semarang}

The promotion regression coefficient is 0.167 . The promotion regression coefficient is positive. It shows that every increase in the promotion variable is 1 (one) and the price variable, service quality, product quality, product diversity, location is 0 (fixed), the promotion variable "P" Coffee has increased by 0.167. The results of statistical calculations with partial tests show that promotion has a positive and significant effect on consumer satisfaction "P" Coffee Semarang because it produces a significance value of $0.044<\alpha=$ 0.05. The hypothesis that has been formulated according to the results of the study, namely promotion, has a positive and significant effect on customer satisfaction "P" Coffee Semarang. According to Stanton (1994), advertising is an element in the sales mix that affects the purchasing decision. The strong influence of promotion on the decision of visitors to visit "P" Coffee Semarang, because consumers think that the promotions carried out by "P" Coffee Semarang provide interesting enough pictures and designs, so consumers are curious to get information and visit "P" Coffee Semarang. This directly shows that the promotion that has been carried out by the manager of "P" Coffee Semarang affects customer satisfaction. This is in line with research conducted by (Kristiana 2014), which shows that promotion has a significant effect on customer satisfaction.

\section{The Effect of Location on Customer Satisfaction "P" Coffee Semarang}

The location regression coefficient is positive. It shows that every increase in the location variable is 1 (one) and the price variable, service quality, product quality, product diversity, and promotion is 0 (fixed). The location variable "P" Coffee has increased by 0.149. Based on the statistical calculation results with partial tests, the location positively and significantly affects consumer satisfaction "P" Coffee Semarang because it produces a significance value of $0.034<\alpha=0.05$. The hypothesis that has been formulated according to the results of the study, namely location, has a positive and significant effect on customer satisfaction "P" Coffee Semarang. This indicates that the more strategic the area, the higher customer satisfaction.

Conversely, the less strategic, the lower customer satisfaction "P" Coffee Semarang. Strategic location is a good location, and it affects the existence of various kinds of other businesses/activities, both economic and social. The location of "P" Coffee Semarang is 
very strategic because it is easy to reach, and the road conditions are wide so that it is easy to pass by two-wheeled or four-wheeled vehicles. The location of "P" Coffee Semarang is also easy to find or search using the Google Map (GPS) application. This is because it is close to the city center, and there are clear directions to the location, making it easier for consumers to go to "P" Coffee Semarang. The place to do business is an essential task for entrepreneurs because, in the right location, a company will be more successful than other entrepreneurs who are less strategically located even though they sell the same product. According to Peter (2000), a good location will guarantee fast access and attract many consumers and is strong enough to change consumer shopping and purchasing patterns. This is supported by research conducted (Nazah et al., 2017), which states that location has a positive and significant effect on customer satisfaction.

\section{Conclusion}

Data analysis and discussion results show that price, service quality, product quality, product diversity, promotion, and location have a positive and significant effect because all independent variables have a considerable probability value $<0.05$. The coefficient of determination showed 0.845 or $84.5 \%$.

\section{Recommendations}

"P" Coffee Semarang parties need to increase the variety of products in the form of completeness, brand, and type. The "P" Coffee Semarang party needs to provide a particular parking area to feel comfortable because "P" Koffie is located in a shopping area, which results in the lack of parking for consumers.

\section{References}

Alim, S. A., Mawardi, M. K., \& Bafadhal, A. S. (2018). Pengaruh Persepsi Label Halal Dan Kualitas Produk Terhadap Keputusan Pembelian Produk Fesyen Muslim ( Survei pada Pelanggan Produk Zoya Muslim di Kota Malang ). Jurnal Administrasi Bisnis.

Amir, M. (2018). Pengaruh Kualitas Produk Terhadap Kepuasan Konsumen Pengguna Notebook Acer Pada PT. Genius Alva Makassar. E-Journal STIE Nobel.

Furkoni, R. A., Hartini, S., \& Andria, F. (2019). Hubungan Kualitas Pelayanan Dengan Kepuasan Pelanggan Pada CV. Bengkel Barokah Motor Bogor. Jurnal Online Mahasiswa.

Habibah, U., \& Sumiati. (2016). Pengaruh Kualitas Produk dan Harga Terhadap Keputusan Pembelian Produk Kosmetik Wardah di Kota Bangkalan Madura. Jurnal Ekonomi Dan Bisnis.

Kotler, Philip,. Keller, K. L. (2016). Marketing Management (15th ed.). Pearson Prentice.

Kotler, P. (1997). Manajemen PemasaranEdisi Bahasa Indonesia jilid satu. Prentice Hall.

Kristiana, D. (2014). Pengaruh Kualitas Produk Terhadap Kepuasan Pelanggan Di Rumah Makan "Lesehan 88" Madiun. EQUILIBRIUM. Jurnal Ilmiah Ekonomi Dan Pembelajarannya.

Lupiyoadi. (2016). Manajemen Pemasaran Jasa Berbasis Kompetensi. Salemba Empat.

Nazah, I. S., Hartati, T., \& Siambaton, E. 
(2017). Pengaruh Atribut Produk Terhadap Keputusan Pembelian Iphone. Jurnal Epigram.

R, Z. F., Puspitasari, N. B., Susanty, A., Andini, A. R., \& Rumita, R. (2020). Analisis Logistic Service Quality Untuk Meningkatkan Kualitas Layanan Jasa Pengiriman JNE Express. Jurnal Teknik Industri.

Rahman, A. (2010). Panduan Pelaksanaan Administrasi Pajak Untuk Karyawan, Pelaku Bisnis, dan Perusahaan. Nuansa.

Sufiyanti, E., Sayutu, A. J., \& Windarti, A. O. (2017). Tingkat Kepuasan Konsumen Terhadap Kualitas Pelayanan Minimarket. Jurnal Riset Bisnis Dan Investasi.

Sugiyono. (2017). In Metode Penelitian Kuantitatif, Kualitatif, dan REDD. CV Alfabeta.

Swastha, B. (2002). Manajemen Pemasaran. Liberty.

Tjiptono, F. (2014). Pemasaran Jasa - Prinsip, Penerapan, dan Penelitian. Andi Offset. 
Journal of Digital Marketing And Halal Industry

Vol. 2, No. 2 (2020) 155-166

http://journal.walisongo.ac.id/index.php/JDMHI/index DOI: http://dx.doi.org/10.21580/jdmhi.2020.2.2.6352

$166 \mid \mathrm{P}$ a g e 